\title{
MEMBANGUN SECURE ATTACHMENT DENGAN ANAK PADA IBU BEKERJA
}

\author{
Oleh: Nurul Qomariah, M.Pd \\ Dosen PIAUD IAIN Syaikh Abdurrahman Siddik Bangka Belitung \\ Email: nurulqomariah740@gmail.com
}

\begin{abstract}
Seorang ibu bekerja berada dalam dilema antara kebutuhan anak dan pekerjaan. Bila memilih pekerjaan maka waktu untuk membersamai tumbuh kembang anak menjadi berkurang, sehingga mengharuskan pengasuhan anak dialihkan kepada orang lain selama bekerja. Namun, harus disadari bahwa kuantitas waktu bersama anak tidak menjamin kualitas hubungan attachment antara ibu dengan anak. Oleh sebab itu, meski bekerja seorang ibu dapat membangun secure attachment dengan anak, agar anak dapat mencapai perkembangan yang optimal, terutama perkembangan kognitif, sosial dan emosional yang dinilai sangat dipengaruhi oleh attachment antara ibu dan anak.
\end{abstract}

Keyword: Attachment, child, working mother

\section{A. PENDAHULUAN}

Attachment atau disebut dengan kelekatan merupakan salah satu hal harus menjadi perhatian orang tua pada awal kehidupan anak. Hal tersebut didasarkan pada sebuah riset yang dilakukan oleh Allen dkk yang menunjukkan bahwa pada perkembangan anak yang normal faktor kelekatan sangat mempengaruhi anak sejak dari lahir hingga usia dua tahun. ${ }^{1}$ Diperkuat oleh pendapat Santrock yang menekankan bahwa pada tahun awal kehidupan anak penting bagi orang tua mengembangkan kelekatan dengan anak. ${ }^{2}$

Anak yang baru lahir sesungguhnya sudah memiliki kecenderungan alami untuk mengembangkan kelekatan dengan melakukan penyesuaian sosial dan berinteraksi dengan orang di sekitarnya. Hal dikarenakan masih terbatasnya kemampuan mereka, sehingga membutuhkan pengasuhan dari orang lain dalam mempertahankan hidup. Oleh sebab itu, dalam semua kebudayaan anak mengembangkan kelekatan dengan orang yang mengasuh, terutama dengan ibu. ${ }^{3}$

1 Joseph P. Allen et al., "A secure Base In Adolescence: Markers of Attachment Security in the Mother Adolescent Relationship', Child Development, Vol. 74, No. 1 (Wiley Online Library, 2003), hlm. 292-307.

2 John W. Santrock, Perkembangan anak, (Jakarta: Erlangga, Edisi Kesebelas, Jilid 2, 2007), hlm. 36.

${ }^{3}$ Desmita, Psikologi Perkembangan, (Bandung: Remaja Rosdakarya, cet ke-8, 2013), hlm. 119. 
Kelekatan pada ibu yang merupakan suatu langkah awal dalam proses perkembangan anak ${ }^{4}$, terlebih ibu merupakan pengasuh utama yang bertanggung jawab atas pengasuhan anak. Secara langsung sejak lahir anak sudah memiliki kelekatan dengan ibu, namun kulitas kelekatan tersebut akan berbeda tergantung dari tingkat respons ibu terhadap kebutuhan anak.

Hal yang harus disadari bahwa responsivitas ibu terhadap kebutuhan anak akan menentukan bentuk kelekatan. Ainswoth menjelaskan bahwa ada dua bentuk kelekatan anak dengan ibunya. Pertama, kelekatan yang aman (secure attachment). Pada bentuk kelekatan ini anak merasa aman dengan ibunya dan ia mengeksplorasi lingkungan melalui Sang ibu. Kedua, kelakatan yang tidak aman (insecure attachment). Bentuk kelekatan ini kemudian dibagi lagi menjadi tiga, 1)kelekatan kecemasan dan menghindar (anxios-avoidant attachment), yakni bila berpisah dengan ibunya anak menunjukkan tanda-tanda cemas dan merasa terganggu dan jika bertemu kembali ia cenderung tidak peduli bahkan menghindari atau menolak bila ibunya hendak menenangkannya. 2)kelekatan kecemasan dan penolakan (anxios-resistant attachment), yakni anak jarang menangis bila berpisah dengan Sang ibu, dan anak akan menunjukkan tingkah laku mendekati atau menolak ketika bertemu ibu kembali, bahkan mengabaikan ibunya. 3) kelekatan yang tidak berorientasi (disoriented attachment), yakni anak merasa tidak aman, senang menyendiri, merasa tertekan atau kikuk, dan menunjukkan sikap tidak berorientasi ketika berkumpul dengan ibunya. ${ }^{5}$ Di antara beberapa bentuk kelekatan tersebut, kelekatan aman (secure attachment) dinilai sebagai bentuk kelekatan yang baik untuk anak dibandingkan dengan bentuk kelekatan lainnya.

Data dari World Health Organization (WHO) pada tahun 2004 menunjukkan 55\% anak dikategorikan dalam bentuk secure attachment dan 43\% dikategorikan dalam bentuk insecure attachment yang dibagi dalam tiga bentuk kelekatan yakni: 20\% anak termasuk dalam bentuk insecure anxios-avoidantc, 15\% anak masuk dalam bentuk insecure anxios-resistant, dan terakhir dengan jumlah $8 \%$ anak termasuk dalam bentuk insecure-disorganized. ${ }^{6}$

Dari data tersebut diketahui bahwa jumlah anak dengan insecure attachment hampir separuh dari jumlah populasi. Hal tersebut menunjukkan bahwa akan ada kemungkinan jumlah tersebut bertambah bila seorang ibu tidak memperhatikan kelekatan yang aman dengan anak, terutama oleh ibu bekerja. Menjadi ibu bekerja memiliki dampak yang kemudian dapat membuat dilema. Di

\footnotetext{
4 Allen et al., 'A Secure Base In Adolescence: Markers of Attachment Security In The Mother Adolescent Relationship'.

${ }^{5}$ Desmita, 'Psikologi Perkembangan', hlm. 123.

${ }^{6}$ Eka Oktavianto, Pelatihan Bermain dan Kekelekatanan Anak Ibu, 'Pelatihan Bermain Pada Ibu Meningkatkan Kekelekatanan Anak', Medisains, vol. 16, no. 3 (2018), hlm. 121.
} 
antaranya yakni ibu harus mengalihkan peran pengasuhan kepada orang lain ketika sedang bekerja, sehingga menyebabkan berkurangnya kuantitas waktu bersama anak. Salah satu resiko yang paling dikhawatirkan adalah anak tidak menjadikan ibu sebagai figur kelekatan, sehingga timbulnya kelekatan yang tidak aman (insecure attachment) dengan anak.

Kekhawatiran tersebut bukan tanpa alasan. Sebab anak dengan insecure attachment biasanya menunjukkan sikap menolak ibunya atau bersikap resistant attachment, takut terhadap orang asing dan merasa sedih serta terganggu oleh perpisahan yang terjadi sehari-hari dengan ibunya. Kemudian pada pertambahan usia hasil penelitian membuktikan bahwa anak dengan secure attachment akan menjadi anak yang kompeten dalam perkembangan sosial, emosional dan kognitif dibandingkan anak dengan insecure attachment. ${ }^{7}$ Grosman dan Grosman menemukan bahwa dalam melaksanakan sebuah tugas anak dengan secure attachment lebih mampu menangani tugas yang sulit dan tidak cepat berputus asa. ${ }^{8}$ Dengan demikian, meski disibukkan oleh pekerjaan dan waktu yang berkurang sebab bekerja, seorang ibu tetap harus memperhatikan kelekatan dengan anak karena kelekatan merupakan pondasi dasar yang mendukung perkembangan mereka di kemudian hari.

\section{B. PEMBAHASAN}

\section{Attachment pada Anak Usia Dini}

John Bowlby, seorang Psikolog dari Inggris merupakan orang yang pertama kali mengemukakan tentang attachment (kelakatan) pada anak di tahun 1958. Ia menuturkan bahwa kelekatan merupakan suatu bentuk perilaku yang membuat seorang individu akan mempertahankan hubungannya dengan beberapa individu lain yang dinilai lebih mampu menghadapi dan mengatasi permasalahan lingkungan. Kelekatan juga merupakan suatu hubungan emosional antara anak dan pengasuhnya yang mana antar mereka saling memberikan kontribusi terhadap hubungan mereka. ${ }^{9}$

Menurut Martin Herbet attachment merupakan ikatan dua orang atau lebih dalam hubungan yang bersifat mengikat dalam ruang dan rentang waktu tertentu. ${ }^{10}$ Sama halnya dengan pendapat Ainsworth mengatakan bahwa kelekatan merupakan sebuah ikatan emosional yang dibentuk seorang individu dengan orang lain yang bersifat spesifik dan mengikat dalam suatu keadaan dan

\footnotetext{
${ }^{7}$ Santrock, 'Perkembangan Anak', hlm. 40.

${ }^{8}$ Eka Ervika, Kelekatan (Attachment) Pada Anak. e-USU Repository (Medan: Program Studi Psikologi, Fakultas Kedokteran, Universitas Sumatra Utara, 2005), hlm. 3.

${ }^{9}$ Diane E. Papalia, dkk, Human development (Jakarta: Salemba, 2009), hlm. 278.

${ }^{10}$ Desmita, 'Psikologi Perkembangan', hlm. 120.
} 
bersifat kekal sepanjang waktu ${ }^{11}$. Kemudian Santrock menjelaskan dengan singkat bahwa kelekatan adalah hubungan erat diantara dua orang yang terikat oleh emosional. ${ }^{12}$

Dari beberapa pendapat di atas pendapat Monk memperjelaskan definisi kelekatan pada anak yakni perilaku anak dalam mencari dan mempertahankan kontak dengan orang-orang tertentu, seperti ibu, ayah, pengasuh dan saudara-saudara dekatnya. ${ }^{13}$

Namun ikatan yang bersifat emosional tidak semuanya dapat disebut kelekatan. Dikatakan adanya hubungan kelekatan bila memiliki beberapa elemen berikut, yaitu 1) kelekatan tersebut merupakan hubungan emosi dengan orang yang spesial dan bertahan dalam rentang waktu yang lama, 2) dalam kelekatan menimbulkan rasa aman, nyaman dan bahagia, dan 3) bila ketiadaan akan tetap ada walau tidak tampak dan akan menimbulkan perasaan kehilangan dan sedih, serta meningkatkan rasa menyesal dan kecewa. ${ }^{14}$

Menurut Maccoby dikatakan anak memiliki kelekatan pada orang lain apabila terdapat ciriciri sebagai berikut:

a. Ada kelekatan fisik

b. Bila berpisah darii figur kelekatan anak menjadi cemas dan akan gembira bila berjumpa kembali

c. Figur kelekatan akan tetap menjadi orientasi anak meskipun tidak ada interaksi.

d. Gerakan figur kelekatan selalu diperhatikan anak, anak memperdengarkan suaranya dan ia berusaha mendapatkan perhatian dari figur kelekatannya. ${ }^{15}$

Dengan demikian, suatu ikatan emosional dikatakan adanya kelekatan apabila dalam hubungan tersebut anak memiliki kecenderungan mempertahankan kedekatan dan ikatan yang emosional yang kuat. Hal ini agar anakdapat memperoleh kepercayaan diri dalam interaksi dan bereksplorasi, serta ia memperoleh kenyamanan dan ketenangan.

\section{Tahap Perkembangan Kelekatan}

Selanjutnya Bowlby menjelaskan bahwa attachment berkembang melalui serangkaian tahap, yang sebagian ditentukan oleh perubahan kognitif dan sebagian oleh interaksi antara anak dengan

11 Ani Wijirahayu, dkk, 'Kekelekatanan Ibu Anak, Pertumbuhan Anak dan Perkembangan Sosial Emosi Anak Usia prasekolah', Jurnal Ilmu Keluarga dan Konsumen, vol. 9, no. 3 (2017), hlm. 171-82.

12 John W. Santrock, 'Perkembangan anak', hlm. 36.

13 Franz Josef Monks, dkk, Psikologi Perkembangan: Pengantar dalam Berbagai Bagiannya (Yogyakarta: Gadjah Mada UP, 1985), hlm. 110.

${ }^{14}$ Ervika, Kelekatan (Attachment) Pada Anak, hlm. 4.

15 Ibid. 
pengasuh. Berikut empat tahap yang diidentifikasi oleh Bowlby pada perkembangan attachment pada anak. ${ }^{16}$

\begin{tabular}{|c|c|c|}
\hline Tahap & Usia/Bulan & Tingkah Laku \\
\hline $\begin{array}{l}\text { Tahap } 1 \\
\text { Prakelekatan }\end{array}$ & $0-2$ bulan & $\begin{array}{l}\text { Anak tidak dapat membedakan orang-orang yang ada di } \\
\text { sekitarnya dan ia merasa senang dengan semua orang, atau } \\
\text { menerima dengan senang orang yang dikenal dan yang } \\
\text { tidak dikenal. Semua orang dapat menyebabkan anak } \\
\text { menangis dan tersenyum. Pada tahap ini anak sudah } \\
\text { mengenali suara dan bau ibunya, tetapi kelekatan belum } \\
\text { dialami anak karena anak tidak ada masalah bila ditinggal } \\
\text { bersama orang dewasa lain yang belum dikenal. }\end{array}$ \\
\hline $\begin{array}{l}\text { Tahap } 2 \\
\text { Pembentukan } \\
\text { kelekatan }\end{array}$ & 2-7 bulan & $\begin{array}{l}\text { Selama pada tahap ini, respon yang diberikan anak kepada } \\
\text { seseorang yang akrab dan orang asing akan berbeda. Anak } \\
\text { sudah dapat mengakui dan menyukai orang lain yang } \\
\text { kenal, bahkan ia mudah tersenyum dengan orang yang } \\
\text { lebih dikenal. Ia mulai mengembangkan rasa percaya (sense } \\
\text { of trust), bahwa ibu atau pengasuh akan merespons saat ia } \\
\text { memberikan sinyal. }\end{array}$ \\
\hline $\begin{array}{l}\text { Tahap } 3 \\
\text { Kelekatan "tegas" }\end{array}$ & 7-24 bulan & $\begin{array}{l}\text { Pada tahap ini kelekatan anak dengan ibu dan pengasuh } \\
\text { lainnya sudah terlihat. Anak telah mengembangkan } \\
\text { keterikatan dengan ibu atau dengan pengasuh pertama } \\
\text { lainnya dan berusaha senantiasa dekat. Anak akan } \\
\text { menangis ketika berpisah dengannya, bila dekat ia akan } \\
\text { aktif berkomunikasi. Selain itu, anak mulai menunjukkan } \\
\text { kekhawatiran dan malu terhadap orang yang tidak dikenal } \\
\text { dan memperlihatkan reaksi terhadap orang yang tidak } \\
\text { dikenal tersebut ketika didekati. }\end{array}$ \\
\hline $\begin{array}{l}\text { Tahap } 4 \\
\text { Goal-coordinated } \\
\text { partenership }\end{array}$ & $\begin{array}{l}24 \text { bulan - } \\
\text { seterusnya }\end{array}$ & $\begin{array}{l}\text { Diakhir tahun kedua, pertumbuhan anak dalam } \\
\text { representasi dan bahasa sangat pesat yang akan membantu } \\
\text { anak memahami sejumlah faktor hal mempengaruhi }\end{array}$ \\
\hline
\end{tabular}

${ }^{16}$ Desmita, 'Psikologi Perkembangan', hlm. 121. 


\begin{tabular}{|l|l|}
\hline \multirow{2}{|l|}{} & $\begin{array}{l}\text { kedatangan dan perginya orangtua serta ia dapat } \\
\text { memprediksi kedatangan kembali orangtuanya. Oleh } \\
\text { sebab itu, anak tidak merasa sedih dan protes terhadap } \\
\text { keterpisahan menjadi berkurang. Selain itu, anak sudah } \\
\text { mulai bisa mempertimbangkan setiap tindakan yang akan } \\
\text { dilakukan. }\end{array}$ \\
\hline
\end{tabular}

\section{Figur dan Tingkah Laku Kelekatan}

Mengenai figur kelekatan menurut Bowlby ada dua, yakni pertama figur kelekatan utama dan yang kedua figur kelekatan pengganti. Figur kelekatan pertama adalah orang yang selalu siap merespon segala kebutuhan anak sekaligus memberikan perawatan fisik. Adapun figur pengganti yaitu orang yang merespon tangisan anak tetapi ia tidak memberikan perawatan fisik. Sedangkan orang yang tidak responsif terhadap kebutuhan anak dan perawatan fisik yang diberikan hanya kadang-kadang maka ia tidak akan dipilih menjadi figur kelekatan oleh anak. ${ }^{17}$

Kelekatan dapat timbul antara anak dengan orang tua atau orang lain apabila dalam keadaan berikut ini: ${ }^{18}$

a. Pengasuh Anak

Pengasuh bukan hanya menemani anak, tetapi berhubungan dengan apa yang dilakukan untuk anak, sehingga yang disebut sebagai pengasuh anak yakni orang yang memiliki hubungan dekat dengan anak dan memiliki tujuan untuk mendidik dan membesarkan anak. Seorang pengasuh anak akan memperhatikan kualitas kelekatan dengan anak dan hubungan yang dilakukan secara berkesinambungan.

b. Komposisi dalam Keluarga

Di dalam keluarga ada kemungkinan bagi anak untuk memilih salah satu dari orang-orang yang ada untuk menjadi figur kelekatannya. Anak akan memilih figur kelekatan yang memenuhi persyaratan sebagai pengasuh dan biasanya seorang ibu menduduki peringkat pertama sebagai figur kelekatan utama anak. Hal ini dikarenakan interaksi yang intens antara ibu dengan anak dan ibu merupakan orang yang dapat memenuhi kebutuhannya serta mampu memberikan rasa nyaman.

${ }^{17}$ Eka Ervika, Kekelekatanan (Attachment) Pada Anak, hlm. 10.

${ }^{18}$ Ibid. 
Meski kuantitas waktu ibu lebih banyak bersama anak tidak menjadi jaminan dapat terjadi kelekatan, karena kualitas dalam hubungan menjadi faktor penting. Seorang ibu ketika berinteraksi dengan anak terkadang tidak mementingkan kualitas, sehingga yang dilakukan bersama anak hanya sekedar untuk tampak di depan anak dan hanya untuk memenuhi kewajiban merawat anak. Hal ini dapat terjadi dikarenakan sikap ibu yang tidak responsif yang terkadang mengabaikan anak. Oleh sebab itu, dewasa ini tidak jarang seorang ayah lebih dipilih anak sebagai figur kelekatan meski anak menghabiskan waktu lebih banyak bersama ibu. Keterbatasan waktu bersama anak menjadi pemicu seorang ayah untuk mementingkan kualitas interaksi dengan anak, bahkan ayah-ayah sekarang cenderung mau terlibat dalam pemeliharaan anak.

Setelah anak memilih figur kelekatan, anak akan menunjukkan tingkah laku kelekatan terhadap figur. Menurut Ainsworth tingkah laku kelekatan adalah tingkah laku yang dilakukan anak untuk mencari, menambah dan mempertahankan kedekatan serta melakukan komunikasi dengan figur kelekatan. Tingkah laku kelekatan dapat dilihat, namun perilaku ini kadang dapat muncul dan kadang tidak. Intensitas perilaku kelekatan anak sangat bervariasi dan tergantung pada situasi lingkungan dan tingkah laku kelekatan ini ditujukan pada figur tertentu dan tidak ditujukan pada semua orang. ${ }^{19}$

Tingkah laku kelekatan anak bervariasi dan dapat tampak pada semua anak. Tingkah laku ini biasanya dipergunakan anak untuk mencari dan mempertahankan kedekatan. Adapun tujuan yang diharapkan dari tingkah kelekatan adalah kedekatan dengan ibu atau pengasuh lainnya. Adapun variasi tingkah laku kelekatan pada anak dikelompokkan menjadi dua bentuk, yaitu sebagai berikut: ${ }^{20}$

a. Signaling Behavior. Bentuk perilaku anak pada signaling behavior seperti menangis, tersenyum dan meraban, mengacung tangan dan mecoba menarik perhatian figur kelekatan.

1) Menangis

Tangisan anak timbul tergantung dari kondisi, termasuk intensitas dan ritmenya. Maccoby menyebutkan bahwa ada tiga jenis bentuk tangisan anak, yaitu tangisan karena takut, tangisan karena lapar dan tangisan karena sakit. Tangisan karena takut akan muncul secara mendadak, diikuti volume yang keras dan ketika anak menarik nafas diikuti keheningan yang cukup panjang. Selanjutnya tangisan karena sakit biasanya terjadi secara mendadak juga dan ini sering terjadi pada anak-anak. Terakhir tangisan karena lapar akan

${ }^{19}$ Ibid., hlm. 6.

${ }^{20}$ Ibid., hlm. 8-10. 
terjadi ketika anak merasakan lapar. Durasi tangisan ini dimulai dengan tangisan biasa sekitar 0,6 detik diikuti dengan keheningan singkat sekitar 0,2 detik dengan bunyi nafas pendek 0,1-0,2 detik dan diikuti periode istirahat singkat.

2) Tersenyum dan meraban

Tingkah laku anak tersenyum dan meraban biasanya dimulai dari usia anak empat minggu. Munculnya ingkah laku ini ketika anak bangun kemudian sadar dan merasa senang. Hal ini menandakan bahwa anak dalam keadaan sehat, tidak lapar dan dan tidak merasa sendirian. Ketika anak menunjukkan tingkah laku tersenyum dan meraban biasanya ibu akan merespon dengan tersenyum kembali, mengajak berbicara, membelai, menepuk, mengangkat dan menunjukkan kebahagiaan terhadap anak. Tingkah laku ini disebut sebagai maternal loving behavior dan dilakukan anak dengan tujuan untuk mendapatkan reaksi dari ibu, dan kelekatan anak dengan figur kelekatan semakin besar dan dapat dipertahankan dalam jangka waktu yang lama.

3) Mengacung tangan

Saat anak berusia enam bulan anak sudah mampu untuk mengangkat tangan ketika berada di dekat ibunya. Isyarat yang ditangkap anak dari ibu selalu diartikan anak dengan mengancungkan kedua tangannya. Acungan tangan ini kemudian diartikan oleh ibu bahwa anak ingin diangkat dan digendong. Anak akan menunjukkan sikap ini anak ketika ia sudah dapat merangkak atau sedang belajar berjalan.

4) Mencoba menarik perhatian

Anak mencoba menarik perhatian ibu dianggap salah satu perilaku yang menandakan bahwa anak merasa dekat dengan ibu. Sikap ini akan ditunjukkan anak mulai rentang usia 32 minggu atau 34 minggu, dengan berusaha mencari perhatian ibu dan ia tidak akan puas sebelum mereka mendapatkan perhatian dari figur kelekatan.

Adapun tujuan dari signaling behavior yang ditunjukkan anak kepada ibu atau figur lekat lainnya adalah membuat mereka mendekat. Apabila mendekat, maka anak berhasil mencapai tujuan untuk mendapatkan dan semakin dekat dengan ibu.

b. Approaching Behavior. Tingkah laku yang termasuk dalam approaching behavior yakni anak mendekat, mengikuti, memeluk, dan menghisap. Pada tingkah laku ini anak yang mendekati ibunya. Hal ini membuktikan bahwa anak mempunyai kecenderungan untuk selalu dekat dengan orang lain.

1) Mendekat dan mengikuti 
Tingkah laku anak mendekat dan mendekati ibunya akan tampak pada anak usia delapan bulan, yaitu ketika kemampuan lokomotor anak sudah muncul. Pada tingkah laku ini anak akan berusaha menyesuaikan gerakannya dengan figur kelekatan dalam rangka mencari atau mempertahankan kedekatan dengan figur. Tingkah laku ini akan muncul beriringan dengan meningkatnya kemampuan kognisi anak.

2) Clinging

Clinging merupakan gerakan anak memeluk ibu ketika terjadi kontak yang sangat dekat. Tingkah laku clinging sangat kuat ketika anak pada usia empat tahun, dan akan memuncak apabila ada tanda bahaya atau reunion setelah perpisahan singkat dengan ibu. Clinging akan tampak pada situasi seperti ketika anak merasa gelisah, takut, khawatir atau merasa rasa amannya terancam, sehingga ia memeluk ibunya untuk mendapatkan rasa aman dan nyaman.

3) Menghisap

Dalam sebuah observasi oleh Hinde diperoleh sebuah kesimpulan bahwa tingkah laku kelekatan juga ditunjukkan anak melalui mulut untuk menghisap dengan kuat puting susu ibunya. Berdasarkan hasil observasi tersebut diketahui bahwa nipple grasping dan sucking mempunyai fungsi yaitu: a) anak akan mendapatkan makanan sesuai kebutuhan; b) menghisap merupakan salah satu bentuk tingkah laku kelekatan yang disebut non nutricial sucking. Tingkah laku ini dapat ditemukan pada anak yang menghisap dot atau menghisap ibu jari. Meski tidak memerlukan makanan anak terkadang menunjukkan tingkah laku menghisap. Menghisap biasanya membuat bayi merasa relaks. Oleh karena itu, disebut sebagai bagian tingkah laku kelekatan dan mempunyai unsur kedekatan dengan ibu.

Dari kedua variasi tingkah laku kelekatan anak, tingkah laku anak variasi kelekatan signaling Behavior menyebabkan seorang ibu mendekati anak, sedangkan pada approaching Behavior anak yang mendekati ibu sebab adanya keterikatan anak dengan Sang ibu.

\section{Faktor yang Mempengaruhi Kelekatan}

Laura menjelaskan bahwa kelekatan pada perkembangannya dipengaruhi oleh beberapa faktor, di antaranya peluang kelekatan, kualitas pengasuhan, karakteristik anak, dan kondisi keluarga. ${ }^{21}$

${ }^{21}$ Laura Berk, Development Through the Lifespan (Yogyakarta: Pustaka Pelajar, 2004), hlm. 262-264. 
a. Peluang kelekatan

Apa yang akan terjadi jika anak tidak memiliki kesempatan panjang untuk menjalani kedekatan dengan ibu atau pengasuh lainnya? Sebuah penelitian mengamati perkembangan anak-anak dalam sebuah institusi dengan pengasuh yang baik dan memiliki fasilitas buku dan mainan. Namun, pergantian pengasuh mengganggu perkembangan kelekatan pada anak. Anak jadi mempunyai keinginan berlebih akan perhatian orang dewasa. Selanjutnya anak dapat mengalami gangguan pada perkembangan kognitif, adanya penolakan terhadap rekan sebaya, serta muncul perilaku mengganggu. Singkat kata, bukti tersebut menunjukkan bahwa kelekatan pada anak bergantung kepada peluang pembentukan hubungan anak dengan ibu atau pengasuh lainnya.

b. Kualitas pengasuhan

Kualitas pengasuhan memiliki pengaruh besar bagi kelekatan anak. Seorang ibu yang responsif, konsisten, memegang anak dengan tepat dan lembut, sangat berkaitan dengan secure attachment. Sebaliknya ibu yang jarang melakukan kontak fisik dengan anak, menangani dengan canggung, bahkan marah dan menolak untuk merespon kebutuhan anak akan membuat anak hidup dengan insecure attachment. Pengasuhan yang tidak memadai akan memiliki hubungan dengan bentuk-bentuk insecure attachment. Oleh sebab itu, kualitas pengasuhan terhadap anak harus menjadi orientasi orangtua.

c. Karakteristik anak

Karakteristik anak berdampak pada seberapa mudah kelekatan tersebut akan terbentuk. Karakteristik anak dengan temperamen emosional reaktif berpeluang untuk mengembangkan bentuk insecure attachment di kemudian hari. Apabila orangtua mampu berupaya menyesuaikan pengasuhan dengan karakteristik dan kebutuhan anak, maka anak dapat memperoleh secure attachment. Akan tetapi apabila kemampuan orang tua terkendala sebab keterbatasan kemampuan atau berada dalam kondisi hidup yang penuh tekanan dan gangguan psikologis lainnya, anak dipastikan akan mengalami masalah insecure attachment atau berada pada bentuk kelekatan tersebut.

d. Kondisi keluarga.

Kondisi keluarga anak, seperti contoh hubungan pernikahan orang tua, ekonomi keluarga, psikologis serta pengasuhan orangtua pada masa kecil akan mempengaruhi kelekatan anak. Kemampuan orangtua dalam mengatasi peristiwa negatif, mengintegrasikan informasi baru dalam pengasuhan anak, dan melihat kembali kehidupan masa kecil yang penuh 
kegembiraan akan sangat mempengaruhi cara membesarkan anak sehingga dapat membentuk secure attachment pada anak.

\section{Membangun Secure Attachment dengan Anak}

Kelekatan tidak terjadi secara alamiah, tetapi melalui serangkaian proses yang dilalui ibu dalam mengasuh anak. Mulai dari anggapan anak ketika lahir mengenai manusia hingga pembentukan kelekatan dengan keluarga, yaitu ibu. Desmita menyebutkan ahli psikologi perkembangan percaya bahwa attachment berkembang sebagi hasil dari interaksi berulang-ulang antara ibu dengan anak. Mereka juga percaya attachment terdiri dari hubungan timbal balik yang sama kuat antara ibu dan anak, walaupun satu sama lain berbeda dalam memenuhi kebutuhan kedekatan fisik dan emosional. ${ }^{22}$

Berikut serangkaian proses yang dapat dilakukan untuk membangun secure attachment seorang ibu bekerja dengan anak.

1. Mengelus perut dan mengajak janin di dalam kandungan berbicara

Hubungan awal ibu dan anak tidak dimulai sejak anak terlahir ke dunia, tetapi sudah dimulai sejak berada di dalam kandungan. Pada usia jnin 20 minggu perkembangan pendengaran di dalam kandungan sudah sempurna, sehingga ia sudah dapat mendengar suarasuara sekitar luar perut ibunya. Selain dapat mendengar suara sekitar, janin juga sudah dapat merasakan sentuhan pada perut Sang ibu. Oleh sebab itu, ketika sedang mengandung ibu sangat disarankan untuk sering mengelus perutnya dan mengajak janin di dalam kandungan berbicara. Perilaku tersebut merupakan cara orangtua mulai membangun secure attachment dengan anak sebelum ia lahir.

2. Menyusui anak

Pada 12 jam pertama kehidupan seorang anak setelah dilahirkan disebut sebagai masa kritis. Sebab kontak satu jam pertama yang dilakukan ibu kepada anak setelah melahirkan selama 30 menit akan memberikan pengalaman mendasar pada anak. Hasil penelitian menunjukkan bahwa anak yang segera didekatkan dengan ibunya setelah melahirkan akan menunjukkan perhatian 50\% lebih besar dibandingkan ibu-ibu yang tidak melakukannya. ${ }^{23} \mathrm{Hal}$ ini menjadi pondasi bagi ibu untuk mengasuh anak dengan baik.

22 Desmita, 'Psikologi Perkembangan Desmita', hlm. 122.

${ }^{23}$ Ervika, Kekelekatanan (Attachment) Pada Anak. hlm. 2. 
Menyusui merupakan awal pembentukan kelekatan anak dengan ibu, bukan hanya untuk mengurangi rasa lapar anak. Dalam hal menyusui ibu disebut sebagai secondary reinforcer sedangkan susu yang diberikan ibu menjadi primary reinforcer. ${ }^{24}$ Pentingnya menyusui karena memberikan efek kenyamanan pada anak. Anak akan lebih gembira dan tidak rewel sehingga kelekatan ibu dan anak dapat dicapai dengan optimal. Pada saat ibu menyusui terjadi kontak fisik dengan anak sehinggaibu dapat melakukan komunikasi hangat dengan anak untuk membangun secure attachment.

3. Peka dan responsif terhadap kebutuhan anak

Secure attachment sangat didukung oleh peran sensitif ibu dalam menanggapi tanda-tanda kebutuhan dan distress pada anak. Ainsworth menyebutkan bahwa sensitivitas orangtua yang didefinisikan sebagai kemampuan orangtua untuk memahami sinyal secara akurat untuk menanggapi mereka segera dan tepat, hal tersebut telah terbukti mempengaruhi perkembangan kelekatan yang aman secara konsisten walaupun dengan cara sederhana. ${ }^{25}$

Pada tahun awal kehidupan, tindakan yang ditunjukkan anak terkait kebutuhannya adalah dengan menangis atau menghisap tangannya. Kemudian seorang ibu akan merespon tindakan anak berdasarkan tingkat kepekaan mereka. Tindakan ibu merespon kebutuhan anak merupakan salah satu faktor terpenting yang menentukan keterikatan antara anak dengan ibu, bahkan menentukan pperkembangan anak. Hal ini berdasarkan hasil penelitian Noordiati yang menunjukkan bahwa kepekaan dan responsivitas pengasuhan seorang ibu terhadap kebutuhan anak mempunyai hubungan yang signifikan terhadap perkembangan anak prasekolah. Anak yang memiliki ibu dengan tingkat kepekaan dan responsivitas yang tinggi mempunyai kemungkinan lebih besar untuk tidak terjadi keterlambatan perkembangan dibandingkan anak dengan ibu yang memiliki kepekaan dan responsivitas rendah. ${ }^{26}$

Menurut Erikson kenyamanan secara fisik dalam pengasuhan anak membentuk basic trust pada anak, yang akhirnya menjadi dasar dari attachment anak dengan ibunya. ${ }^{27}$ Sehingga Bowlby menekankan penting bagi seorang ibu untuk responsif dengan segala tindakan anak, ${ }^{28}$ terutama

\section{${ }^{24}$ Ibid, hlm. 5.}

${ }^{25}$ Mariska Klein Velderman et al., 'Effects of Attachment Based Interventions On Maternal Sensitivity and Infant Attachment: Differential Susceptibility of Highly Reactive Infants.', Journal of Family Psychology, vol. 20, no. 2 (American Psychological Association, 2006), hlm. 266.

26 Noordiati, Mohammad, dkk 'Hubungan Kepekaan Serta Ketanggapan Pengasuhan Ibu Terhadap Perkembangan Anak Prasekolah', Berita Kedokteran Masyarakat, vol. 27, no. 1, hlm. 20.

27 John W. Santrock, 'Perkembangan anak', hlm. 37.

${ }^{28}$ Ibid. 
ketika ia menangis. Semakin besar respon seorang ibu terhadap tindakan yang diberikan anak, maka akan semakin kuat keteriikatan di antara keduanya.

Anak berkaitan dengan kelekatan yang aman menghasilkan perkembangan ke arah positif dalam kehidupan. Sementara respon yang kurang dari orang tua dianggap sebagai faktor risiko yang merugikan bagi perkembangan kehidupan anak. Sebab dengan adanya responsivitas sebagai dasar yang kuat akan menjadikan anak percaya diri dalam bereksplorasi di dunia mereka. ${ }^{29}$

4. Membangun dan menjaga quality time bersama anak dalam keluarga

Hubungan dan kehangatan ibu sangat berperan besar bagi perkembangan anak dalam jangka waktu yang panjang. Ekspresi seorang ibu tentang rasa cinta dalam pengasuhan yang tampak pada perilaku mengemong, memeluk, menghibur, bermain, mengungkapkan kata cinta, dan memuji perilaku anak. Diprediksikan kemampuan kognitif anak, emosional dan sosial akan sama kuatnya dengan kehangatan yang didapat dari ibu. Anak akan mampu menjalani masa kanak-kanak dan remaja dalam hubungan sosial yang baik, mempunyai kepercayaan diri yang tinggi, dan mampu meneguhkan kemampuan mereka dalam menguasai tantangan di masa depan..$^{30}$

Seorang ibu yang memiliki secure attachment dengan anak akan tampak senang mengajak anak berkomunikasi dan bercanda. Sering berinteraksi dengan anak untuk menjaga sensivitas dalam merespon kebutuhan anak dan kehangatan bersama anak akan membuat anak merasa nyaman. Maka, menjadi sebuah keharusan bagi orang untuk untuk membangun dan menjaga quality time bersama anak di dalam keluarga untuk mendukung berbagai aspek perkembangan anak.

5. Menjaga stabilitas kelekatan

Banyak orang sebelum menjadi orang tua mereka belum mempersiapkan diri secara psikologis, tetapi dengan dukungan sosial mereka mampu memainkan peran dengan baik. Tentu dengan peran orangtua yang baik stabilitas kelekatan dengan anak akan terjaga.

Penelitian mengenai stabilitas kelekatan terhadap anak mana yang tetap sama dan berubah antara anak usia 1 dan 2 tahun menghasilkan beberapa temuan. Anak dengan kualitas secure attachment dan stabil biasanya menjalani kehidupan dengan kondisi yang baik. Kemudian anak yang beralih dari kelekatan yang tidak aman menuju kelekatan aman dibersamai oelh ibu

${ }^{29}$ Papalia and Dkk, 'Human development', hlm. 278.

${ }^{30}$ Laura Berk, 'Development Through TheLlifespan', hlm. 269. 
yang memiliki kemampuan adaptasi yang baik dan ikatan keluarga dan pertemanan yang positif. Sebaliknya bila anak berada di dalam keluarga yang memiliki tekanan dan kurang dukungan sosial, maka kelekatan anak bergerak menjauh dari secure attachment atau berubah bentuk insecure attachment lainnya. Temuan pada penelitian tersebut menunjukkan bahwa anak dengan secure attachment lebih sering mempertahankan status kelekatan dibandingkan dengan anak yang insecure attachment. Kemudian anak dengan disoriented attachment dinilai mengalami pengasuhan yang negatif, sehingga pada perkembangan emosi terganggu dan sering bingung serta ambivalen pada orangtua. ${ }^{31}$

\section{KESIMPULAN}

Menjadi ibu bekerja tidak menghalangi untuk membentuk secure attachment dengan anak. Meski bekerja seorang ibu harus tetap menjadi figur lekat bagi anak, sebab perasaan aman dan penuh kasih sayang yang muncul dari secure attachment akan mendukung aspek psikologis anak, termasuk mendukung perkembangan kognitif, perkembangan emosional dan perkembangan sosial. Anak dengan secure attachment dinilai akan berkembang lebih baik pada tahun-tahun berikutnya ketika pada masa remaja dan dewasa.

\footnotetext{
31 Ibid., hlm. 261.
} 


\section{DAFTAR PUSTAKA}

Allen, Joseph P. et al., 'A Secure Base In Adolescence: Markers of Attachment Security In The Mother Adolescent Relationship', Child development, vol. 74, no. 1, Wiley Online Library, 2003, pp. 292-307.

Berk, Laura, Development Through The Lifespan, Yogyakarta: Pustaka Pelajar, 2004.

Bermain, Pelatihan and Kelekatan Anak Ibu, 'Pelatihan Bermain Pada Ibu Meningkatkan Kelekatan Anak', Medisains, vol. 16, no. 3, 2018, p. 121.

Desmita, Psikologi Perkembangan, Bandung: Remaja Rosdakarya, 2013.

Ervika, Eka, Kelekatan (Attachment) Pada Anak. e-USU Repository, Medan: Program Studi Psikologi, Fakultas Kedokteran, Universitas Sumatra Utara, 2005.

Hakimi, Noordiati Mohammad dan Tunjung Wibowo, 'Hubungan Kepekaan Serta Ketanggapan Pengasuhan Ibu Terhadap Perkembangan Anak Prasekolah’, Berita Kedokteran Masyarakat, vol. 27, no. 1 .

Klein Velderman, Mariska et al., 'Effects of Attachment Based Interventions On Maternal Sensitivity and Infant Attachment: Differential Susceptibility Of Highly Reactive Infants.', Journal of family psychology, vol. 20, no. 2, American Psychological Association, 2006.

Mönks, Franz Josef, dkk, Psikologi Perkembangan: Pengantar dalam Berbagai Bagiannya, Gadjah Mada UP, 1985.

Papalia, Diane E. dkk, Human development, Jakarta: Salemba, 2009.

Santrock, John W., 'Perkembangan anak', Jakarta: Erlangga, Edisi Kesebelas, 2007.

Wijirahayu, Ani dkk, 'Kelekatan Ibu Anak, Pertumbuhan Anak dan Perkembangan Sosial Emosi Anak Usia Prasekolah', Jurnal Ilmu Keluarga dan Konsumen, vol. 9, no. 3, 2017. 